\title{
Sophocles' Oedipus Rex: A Deconstructive Study
}

\author{
Javed Akhter (Corresponding author) \\ Department of English Literature and Linguistics \\ University of Balochistan Quetta Balochistan Pakistan \\ E-mail: sangatjavedakhtar@gmail.com \\ Khair Muhammad \\ Department of English Literature and Linguistics \\ University of Balochistan Quetta Balochistan Pakistan \\ E-mail:khairefroze@gmail.com \\ Naila Naz \\ Department of English Literature and Linguistics \\ University of Balochistan Quetta Balochistan Pakistan \\ E-mail: nailanaz005@gmail.com
}

\author{
Doi:10.7575/aiac.alls.v.6n.5p.9 \\ URL: http://dx.doi.org/10.7575/aiac.alls.v.6n.5p.9
}

Received: $19 / 04 / 2015$

Accepted: 04/07/2015

\begin{abstract}
Jacques Derrida (1930-2004) is the most prominent figure in contemporary philosophical and literary debate. He originates a trend-breaking theory of deconstruction. He opines the persistence in west European philosophical tradition of what he labels is logocentric metaphysics of presence. He argues that the different theories of philosophy, from Plato until structuralism are versions of a single or authoritative system. Though we cannot hope to escape this system we can at least identify the conditions of thought it imposes by attending to that which it seek to impress. Derridean deconstruction may present a new perspective to Sophocles' "Oedipus Rex", which has always been a research target for world researchers. The researchers studied it from different angles, but the present study tries to reveal different facets of the play on Derridean deconstructive bedrock. Applying Derrida's deconstruction to the text of the play, the study tries to present it in a new and innovative way. The study will discuss how Western logocentric tradition of the metaphysics of presence and its compelling repercussions ground human thought in stable and pre-determined meaning. In its concluding mode, the study analyses preventive stumbling aporic blocks of fossilized logocentric structure of the minds of characters in the play.
\end{abstract}

Keywords: Jacques Derrida, deconstruction, logocentric metaphysics of presence and messianic, aporia, binary Oppositions

\section{Introduction}

Sophocles (496-406 BC) was one of the three great tragedians of ancient Greece. He was junior to Aeschylus and senior to Euripides. In this respect, he stands midway between Aeschylus and Euripides. He was first playwright who added the third actor into plays. The myth of "Oedipus Rex" constitutes the Theban Plays together with the cycle of "Oedipus at Colonus" and "Antigone" because these plays deal with the Oedipodean family history. However, these three plays do not form a trilogy. Therefore, the play centres on this central question whether Oedipus is actually guilty of assassinating Laius, which lies behind the Theban pestilence? That is why "Oedipus Rex" deals with the tragedy of Oedipus, the King of Thebes. The events of the play antecedent to the opening of the play as follows:

Laius, one of the Theban kings asked The Delphic Oracle of Apollo whether he and his wife Jocasta would have a son. She professed them that their newborn son after he had grown up, would destine to slay his father and marry his mother. In spite of the Delphic Oracle of Apollo, Laius and Jocasta bigoted him. After the birth of Oedipus, Laius ordered his servant, a shepherd to abandon Oedipus in a wooded hollow of the mount Cithaeron. In order to avoid the curse and catastrophe, the king handed over the infant with his feet pierced and a nail driven through his ankles to be exposed. For the herdsman had not the heart to abandon the child to perish in the woods, instead he entrusted it to a fellow-labourer, a Corinthian shepherd, beseeching him to take it away beyond the borders of Thebes and rear it as his own son.

The shepherd was the Corinthian, and servant of Polybius and Merope, the King and Queen of Corinth, mercifully rescued him. In due course, he brought the child to their court and handed him over to the King and Queen. They being the childless couple gladly and warmly welcomed the infant and adopted it as their own son. Therefore, they reared and brought up Oedipus in the royal court as their own child, who in turn regarded them as his own parents. When Oedipus grew to manhood, he destined to hear by chance once more the same terrible prediction from the mouth of Apollo's 
ministers that he was doomed to commit patricide and incest, as that his real parents had heard before his birth many years ago.

However, he decided to flee from his Corinth, seeking to avoid the Delphic Oracle of Apollo. Therefore, he fled from Corinth, resolving never again; to set foot in Corinth and set eyes on his supposed parents as long as they lived. On his journey, he encountered an old man and his servants, quarrelled with and killed them. In fact, he slew his father, Laius and his servants in ignorance by chance, at the crossroad, where the three roads met.

Before entering Thebes, he met the Sphinx, a winged female monster at Thebes, with the body of lion and the head of a woman. She held the city under a spell. She ate man who could not solve her riddle: "what is it that walks on four legs at dawn, two legs at midday, and three legs in the evening and has only one voice; when it walks on most feet, is it weakest?" Creon, appointed ruler of Thebes offered the kingdom and the hand of the recently widowed Queen and his sister Jocasta to anyone who could answer the riddle. Oedipus solved the riddle and set the city free from her spell by solving her riddle correctly, "Man, who crawls in infancy, walks upright in his prime, and leans on a cane in old age." Outraged, the Sphinx destroyed herself and then Oedipus became the King of Thebes and wedded Jocasta, the recently widowed Queen. Moreover, he begot two sons and two daughters from her.

Sophocles begins his tragedy at this point in the legend. He rearranges the events of Oedipus myth already known to the Greek people in more than one version, none of them absolutely true or false and fashions it in his innovative artistic and dramatic form to suit his ideas and purposes. Homer and Aeschylus both already elaborate the Oedipus myth somewhat different from Sophocles. In Homer's account, Oedipus continues his rule after the truth comes out. Whereas in Sophocles" "Oedipus Rex" he gouges his eyes, to poke pins in them and leaves the city forever.

Therefore, Sophocles begins his tragedy after seventeen years of Laius's assassination. Meanwhile Oedipus had married to his mother Jocasta and begotten four children from her. The terrible plague and drought had struck the people of Thebes. During this, at last, the pestilence and famine brought the people of Thebes once more to the verge of utter extinction. However, Oedipus instructed Creon, brother of Jocasta to go and consult the Oracle of Delphi and inquire the causes of the plague and famine. He brought the information about the causes of plague that there would be no relief until the assassinator of Laius was banished from the city. Then Oedipus started an intensive investigation to find the culprit. Therefore, he ordered his servants to search the culprit so that the slayer of Laius might be punished. At last, Teiresias, the bi-sexual blind prophet in anger revealed the truth, charging at Oedipus as a murderer of Laius:

"I say that the killer you are seeking is yourself" (Sophocles, 1947, p. 36).

On hearing these words of Teiresias, Oedipus furiously dismissed him. The sequence of terrible events at last revealed the truth that Oedipus was the slayer of Laius. When this horrible truth had come out Jocasta committed suicide to hang herself, and Oedipus gouged his eyes, using her brooch to stab his eyes so that he could no longer see what he had done. Afterwards he left the city, as a wretched wanderer to punish himself. At last, Thebes was restored to health, abundance and prosperity.

\section{Literature Review}

Sophocles' "Oedipus Rex" is undoubtedly one of the most popular classical plays of the world. This is generally acknowledged one of the world's greatest tragedies, but at the same time, it is a fate-ridden tragedy as well, both in its hero and in its cycle of events. It raises great discussion and debate among the critics of the world from Socrates, Plato and Aristotle's "Poetics" until the critics of the present time that in what ways does Oedipus access the status of a tragic hero. Therefore, it has always been the research focal target for world research scholars.

However, the play generated the greatest amount of critical views and debates. No critic of any period since Socrates, Plato and Aristotle to the present day has been able to neglect the play. Literary theories come and go all the time however, always this play, remains attractive to the critics, like John Keats' "Grecian Urn", to "tease us out of thought/ As doth Eternity", teasing the literary critics of the world into thought. Therefore, it has undergone different academic analyses and interpretations. Much has been written on the play from different angles and opinions until to date. This popular classical literary piece of work is much appreciated in the traditional literary canon not only by the classicists but also by devotees of the large body of Western literature and literary theory.

Moreover, the protagonist, (Oedipus) and the topic of the play have always been a focal point of critical discussion and debate in the world of literature. The different features and characters of the play, especially the central character of the play Oedipus attracted every major psychologist since Sigmund Freud. Therefore, the psychoanalytical critics from F. J. Hoffman until Jacques Lacan interpreted the text of the play from the Freudian theory of psychoanalysis in the terms of Oedipus complex. In this context, Edmund Lowell wrote a paper entitled "The Body of Oedipus" (1988), which is very informative and thought provoking psychoanalytical study of the play.

The structuralist and Poststructuralist critics have also focused their full attention to the semiotic analysis and structuralist narratology of the text of this debate raging play from Claude Levi Strauss to Gilles Deleuze and Felix Gauttari. Claude Levi Strauss analyses the Oedipus myth in his reading "The Theban Plays" in a way, which is truly structuralist in its use of the linguistic and anthropological structuralist model. He calls the units of myth mytheme, which are organised in binary oppositions. In this manner, he argues that the source of every myth lies in the irreducible contradiction between chthonic and autochthonous, "coming from the Earth" and "coming from ourselves" (from sexual union of man and woman.) Therefore, the general polarity underlying the Oedipus myth embodies the conflict between our knowledge that we are born from coition or of sexual union of man and woman and persistent belief among many 
cultures that we are born of the earth. For example, Spartoi spring from the soil in the Oedipus myth, or we may add, as Adam is fashioned from clay in "the Bible".

Claude Levi-Strauss further argues that several mythemes have been arranged on the basis of the antithesis between the overvaluation of kinship relationships. For instance, Oedipus marries his mother, Antigone buries her brother unlawfully and the undervaluation of kinship, for example, Oedipus kills his father, and Eteocles kills his brother (LeviStrauss, Claude, 1974, pp.213-221). John Peradotto wrote a paper entitled "Interrogating the Canon, Deposing the Tyrannus" (1994), which is a semiotic study of the text of the play.

In the present times, the critical analysis of classical texts such as Sophocles' play "Oedipus Rex" is facing the challenges of Post-structuralist Derridean theory of deconstruction to re-examine the premises and presuppositions of the traditional literary canons, methods and theories of research and to replace them with the alternatives. These alternatives can speak in a way that is consonant with Post-structuralist Derridean epistemology. For this reason, the classical texts began to be interpreted from a polysemantic perspective of deconstruction. The aim of deconstructing these classical texts is to interpret them in a new and innovative polysemantic perspective, which are supposed to be as stable logi of mythical stories described in the ancient dramas just as Sophocles" "Oedipus Rex".

In this respect, Ashaq Hussain Parray wrote a research paper entitled "A Postmodern Interpretation of Oedipus Rex" (2012), which focused on the play from the Postmodernist perspectives of Jacques Derrida, Jean Baudrillard and Michael Foucault. In his research paper, the author critically reviewed the traditional and accepted interpretation of the text of the play, "which considers Oedipus as a guilt-ridden soul responsible for the murder of his father and marrying his mother" (Parray, Ashaq Hussain, 2013, p. 106). He explains his aim of study the text in these words: "Insistence on textual analysis is due to the influence of trend-breaking literary giants like Jacques Derrida, Jean Baudrillard and Michael Foucault, who undoubtedly are the chief spokespersons for postmodernism" (Parray, Ashaq Hussain, 2013 , p. 106). None of the critics and researchers applied Derridean deconstruction properly to the text of the play. That is why the present study would be an analysis from a new and innovative perspective on "Oedipus Rex"; applying Derridean deconstructive hermeneutics to the text of this highly debate raging play.

\section{Deconstruction}

Jacques Derrida (1930-2004) is the most prominent figure in the contemporary scenario of academic scholarship, literary theory and philosophical debate. He breaks through the tradition of structuralism and initiates the theory of deconstruction, which has revolutionised many disciplines from philosophy and history, from film studies to law, architecture, politics, anthropology and theory of aesthetics. Deconstruction is a very complex and difficult term not defined explicitly by its originator Jacques Derrida. Nevertheless, he gives some important clues about how to deconstruct a literary piece of work, which may help us define the term. M.A.R. Habib writes that deconstruction is "a way of reading, a mode of writing, and above all, a way of challenging interpretations of the texts based upon conventional notions of stability of human self, the external world, and of language and meaning" (Habib, M.A.R, 2005, p. 649). Jacques Derrida writes about it:

"Deconstruction" is "destruction" and desedimentation of all the significations that have their source in that of the logos" (Derrida, Jacques, 1997, p. 10). It is an attempt to deconstruct this centre in the "logos". However, this does not mean to destroy as Derrida writes, "rather than destroying, it was also necessary to understand how a "whole" was constituted and reconstruct it to the end" (Derrida, Jacques, 2007, p. 3). Therefore, deconstructive reading "must always aim at a certain relationship, unperceived by the writer, between what he commands and what he does not command of the patterns of the language that he uses" (Derrida, Jacques, 1997, p. 158).

In short, deconstruction means to unpack the hidden premises that reigned from Plato's "Phaedrus" until Martin Heidegger's "Origin of Geometry" in a uniform progression unmarked by discontinuities. Jacques Derrida proposes how to deconstruct the literary text or how a deconstructionist reads, by the two potential strategies for disseminating the logocentric system of Western Philosophical tradition. First, it attempts to read without changing ground, by tracing the intrinsic logocentric structure and using the system against it. While the other changes the ground and quickly steps outside by affirming an absolute break and difference (Derrida, Jacques, 1982, 35).

The selection between these two modes of deconstruction is by no means simple and easy task. Jacques Derrida recommends that both deconstructive modes of reading may be employed to the literary text. The very idea of selection, between the two modes of interpretations, shows privileging of one over another. In order to avoid such problems, Jacques Derrida calls for double-reading, and he himself applies this method to read Jean-Jacques Rousseau's "Essay on the Origin of Language" in the second half of his book "Of Grammatology." In this way, he formulates these two modes of interpretation-logocentric and deconstructive firmly in the following words:

"There are thus two interpretations of interpretation, of structure, of sign, of play. The one seeks to decipher, dreams of deciphering a truth or an origin, which escapes play and the order of the sign and which lives the necessity of interpretation as an exile. The other, which, is no longer turned toward the origin, affirms play and tries to pass beyond man and humanism, the name of man being the name of that being who, throughout the history of metaphysics or of ontology---, in other words, throughout his entire history----has dreamed of full presence, the reassuring foundation, the origin and the end of play. The second interpretation, to which Nietzsche pointed the way, does not seek in ethnography, as Levi-Strauss does, the "inspiration of a new humanism" (again citing the "Introduction to the Work of Marcel Mauss”) (Derrida, Jacques, 2005, pp. 369-370). 
The deconstructive mode of reading the text produces a counter-reading of logocentric metaphysics of presence and ontologies of being by scrupulously locating and foregrounding the unnoticed constituting force of difference and writing to shake the firm ground, familiar hierarchies and orders against the grain to reveal a subversive meaning, deferred context, false bottom, and counter-sense. It reveals that the point of reference is deconstructible because it is founded or constructed on the interpretable and transformable textual strata. Therefore, deconstruction is a genealogical analysis of these constructions.

The deconstructive questioning of the subject the given legitimacy, authority and norms of reading makes justice possible, in both literal and metaphorical sense. Nevertheless, the questioning of foundation is not a deliberate strategic change of subject from the controlled superstructure; instead, it is a maximum intensification of a transformation in progress. The formulation of deconstructive process is concerned with two modes. The first, it is an exploration of logocentric meanings and their systematic undoing by meticulous interpretations and genealogical analysis of the subject. While the other demonstrates the presence of meaning without referring to the origin, it is ahistorical and antilogocentric, and proceeds through reading of the text without locating the fixed ground. I follow these two deconstructive processes of interpretation to read Sophocles' "Oedipus Rex" in this paper.

Whether or not perfect understanding always occurs in fact, this image of perfectly self-present meaning, according to Jacques Derrida, is the underlying idea of Western culture. It believes in self-presentation of meaning is what Jacques Derrida terms logocentrism. The meaning of This Greek word logos is speech, logic, reason and the word of God.

While writing is considered by logocentric system to be only a representation of speech, a secondary substitute designed for us only when speaking is impossible. Therefore, writing is a second-rate activity, which tries to overcome distance by making use of it: the writer puts his thought on paper, distancing it from himself, transforming it into something that can be read by someone faraway, even after the writer's death. This inclusion of death, distance, and difference is thought to be a corruption of self-presence of meaning, to open up to all forms of adulteration which immediacy would have prevented. This is what the present study tries to deploy to the text of the play "Oedipus Rex" to unfold it in a deconstructive terms.

\section{Deconstructive Analysis of Sophocles' Oedipus}

This research paper tries to interpret the different facets of the text of Sophocles' most famous play "Oedipus Rex" in a new and novel perspective in terms of Derridean deconstruction. Therefore, the present study tends to interpret Western logocentric tradition of the metaphysics of presence and its compelling repercussions and affects, which ground the thought of the personages of the play in stable and pre-determined meaning. In this manner, Derridean deconstruction and its relative terms are simply relevant to the nature of this research.

Sophocles' "Oedipus Rex" centres on different kinds of the notions and logi of the theocentric, fatecentric and anthropocentric messianic logocentrism. It contains a self-reflexive debate and discussion on the power of logi and their manipulative force and impact on the ancient Greek social formation and its individuals. That is why most of the characters of the play are attached to the notions and logi of the theocentric and anthropocentric messianic logocentrism, which are deeply rooted in the ancient Greek religion, philosophy and culture. For instance, Apollo, sun god possesses messianic theocentric logos and position in the life, religion, mythology and culture of the ancient Greek people. Sophocles mentions Apollo in different names and titles such as King Phoebus, Lord of the Bow, god of the sun, Delian Healer, healing god (born on the Island of Delos, his title is healer because he causes and averts pestilence), Lycean King (his titles is Lykios because he is god of light), and Pytho's god Apollo. These names and titles of Apollo describe his multiple powers over the ancient Greek people.

In addition, Sophocles mentions the other gods and goddesses in the play such as Athena, golden daughter of Zeus, Western god, Ares, War god, Amphitrite, sea goddess, Dionysus, god of wine, Pan, Arcadian shepherd god and Cyllene's king, the messenger god. These gods and goddesses also have powers over the ancient Greek people as well as messianic theocentric logos and position in ancient Greek religion, life and culture. As the following lines of the Chorus of the Theban elders, describe:

"O Healer of Delos, hear!

Fear is upon us. What wilt thou do?

Things new or old as the circling year?

Speak to us, Daughter of Golden Hope! Come, deathless word!

Deathless Athena! First, daughter of Zeus, on thee

We call; then on thy sister Queen

Artemis, over our city enthroned in her majesty;

And Phoebus, Lord of the Bow;

Show us again your threefold power

This hour, as in ages long ago.

From the fire and pain of pestilence save us and make us clean" (Sophocles, 1947, p. 30).

The other example of the ancient Greek people's attachment to the theocentric messianic logocentrism is fatecentrism in the life of the ancient Greek people because the gods are believed to predestine the fate of the people. Sophocles 
describes the fate as will of the gods in the play. In this sense, the play is riddled with fate, destiny, coincidence and counter coincidence. The fate of the tragic hero, Oedipus depends on predetermined events, incidences and counter coincidences. We find that Oedipus is just a toy or puppet in the hands of the gods, who are playing with his life and fate. His life is predetermined by the gods, who reign over every event of his life. The role of the fate is dominant in his life. Therefore, the characters of the play represent all the human beings of the ancient Greece, who are imprisoned in one way and the other in the blind alley of different illusions of the logi of language, philosophy, culture and religion.

The ancient Greek people's mental attachment of the theocentric messianic logocentrism of the fate, which may be evident that the Delphic Oracle (Pythian hearth) of Apollo, god of the sun seems to occupy a special privileged place in the life of the ancient Greeks. She seems to be a link between Apollo, the sun god and the ancient Greek people. She predicts the fate of the people, predestined by the gods. In this sense, she is a source of communication between the gods and the people.

However, the function of the Delphic Oracle of Apollo is to foretell the fortune of the ancient Greek people. For example, she foretells that the new born son of the King Laius and Queen Jocasta will commit patricide and incest in the play "Oedipus Rex". When the child (Oedipus) was born, the King and Queen order their servant to infanticide for averting the curse. The servant did not perish the infant and rescued him. The Oracle of Delphi also professed the same prophesy again to Oedipus, when he grew to man. Therefore, he resolved to flee his city Corinth for averting this curse. Oedipus and Laius both encountered with each other at the spot too narrow for both to pass at precisely the same moment.

Oedipus slew Laius and his servants by chance at the crossroad. Finally, this prophecy proved to be true in the play, making us believe that the gods predestined the fate of man. For this reason, Oedipus and Jocasta, the fated pair has been lived and died ignorant of their tragic fate. At last, Oedipus protested against the punishment of his crime, which he did not commit himself, but some other force made him to commit to do so. He found himself in a helpless situation in which he was just a puppet in the hands of the god Apollo as he describes:

"Apollo, friends, Apollo

Has laid this agony upon me;" (Sophocles, 1947, p. 63)

The other example of the ancient Greek people's attachment of theocentric messianic logocentrism is the privilege given to the Sphinx, a supernatural winged female monster with the body of a lion and the head of a woman. Sophocles describes her as the hooked taloned maid of the ridding speech in the play. The Sphinx held the city of Thebes under a spell. She ate man who could not solve her riddle. As Creon says about her:

"The Sphinx with her riddles forced us to turn our attention

From insoluble mysteries to more immediate matters" (Sophocles, 1947, p. 29).

Oedipus answered her riddle correctly, saved Thebes and on this Creon rewarded him with the hand of recently widowed Queen Jocasta and the kingdom of Thebes. According to the myth, long afterward, Oedipus, old and blinded, wandered the road. He felt a familiar being, which was the Sphinx. Oedipus asked her question. "Why did not I recognize my mother?" "You gave the wrong answer," said the Sphinx. "But that was what made everything possible," said Oedipus. "No," she said. You answered my riddle, Man. You did not say anything about Woman." "When you said Man," said Oedipus, "you included women too. Everyone knew that." She said. "That was what you think."

In addition, Sophocles also mentions other supernatural elements in the play as nymphs, minor female divinities with youthful, beautiful and amorous qualities, which contains some supernatural forces. In this way, the people of Thebes seem to be trapped in a blind alley of messianic logocentric metaphysics of presence and ended in necessary complications of preventive stumbling aporic blocks of fossilized logocentrism.

Another example of the anthropocentric messianic logocentrism is the privileged given to the central character of the play, Oedipus as a god-like figure. He is both anthropocentric and theocentric logos for suppliants of Thebes. They consider him god who can remove their miseries and sufferings. The play opens with the crowd of suppliants before the palace of Oedipus is beseeching him to remove the distress and wretchedness of the pestilence from the city, as if he were a god. The very first words of the Priest fully express the god-like absolute authority the King enjoys over them:

"My Lord and king: we are gathered here, as you see,

Young and old, from the tenderest chicks to the age bent seniors" (Sophocles, 1947, p. 26)

Oedipus as a king and sacrificial scapegoat is bound up with the personal fate of the ruler offers himself up, as a scapegoat is the city redeemer from pestilence and drought to blind his eyes and banish himself from Thebes to punish himself. The link between his theocentric and anthropocentric authority and that of the gods is further established as the priest tells a few lines later that the rest of the population of Thebes is waiting at the two shrines of Pallas and Apollo. They see the royal palace as palace of succour like the three temples of the gods. After reporting the wretched plight of the city, the Priest concludes:

"Now, Oedipus great and glorious, we seek

Your help again. Find some deliverance for us

By any way that god or men can show" (Sophocles, 1947, p. 26). 
In fact, the story of "Oedipus Rex" centres on misrecognition, which is closely meshed with the shift toward a posttraditional subjectivity. This creates the different kinds of aporas in the text of the play. For this reason, Oedipus suffers in the different kinds of aporas in which he cannot decide about his origin, concerning a quest for his identity. Therefore, he finds himself in an aporetic situation, posing the questions:

"Born thus; I seek to be no other man

Than that I am, and will know who I am?" (Sophocles, 1947, p. 55).

In this way, Sophocles decentres Oedipus's logocentralized messianic position and dethrones his god-like authority in the end of the play. This is the delogocentric mode of the text of the play. As Creon says to Oedipus in the end of the play:

"Command no more. Obey. Your rule is ended" (Sophocles, 1947, p. 68).

The other example of the ancient Greek people's attachment to the anthropocentric and theocentric messianic logocentrism is the special privilege given to Teiresias, as prophet or seer. He is a blind prophet who is considered a medium between the Greek people and the gods as the Chorus describes his special privileged position of the theocentric and anthropocentric messianic logocentrism:

"To the lord Phoebus the lord Teiresias

Stands nearest, I would say in divination" (Sophocles, 1947, p. 33).

\section{Binary Oppositions}

Having forged the term deconstruction, Jacques Derrida follows Fredrick Nietzsche and Martin Heidegger in describing a critique of Western metaphysics of presence. He means by Western metaphysics of presence not only Western philosophical tradition but everyday thought and language as well. For him Western philosophy has always been structured in the terms of dichotomies or polarities: such as light versus darkness, virtue versus evil, beauty versus ugliness, being versus nothingness, presence versus absence, truth versus falsehood, identity versus difference, mind versus body, man versus woman, soul versus body, life versus death, nature versus culture, and speech versus writing. Therefore, these polar opposites do not stand as independent and equal entities.

In this hierarchal order, the second term in each pair is considered negative, corrupt and undesirable version of the first, as well as a fall away from it. Hence, absence is the lack of presence, evil is fall from virtue and falsehood is a distortion of truth. The two terms in each pair are not simply opposed in their meanings, but are arranged in a hierarchal order, which one privileges over the first term, in both the temporal and qualitative sense of the word. These hierarchical oppositions privilege unity, identity, immediacy, and temporal and spatial presences over distance, difference, dissimulation and deferment. In seeking for the answer to the question of Being, Western philosophy has indeed always determined Being as presence.

In this way, Jacques Derrida criticises Western metaphysics for its full focus on privileging of the spoken word over written word. It gives a higher value to the spoken word instead of the marked word because the speaker and listener are both present to the utterance simultaneously. There is no temporal and spatial difference between speaker, speech and listener, since the speaker and listener hear at the same moment. This immediacy guarantees the notion that in the spoken word we know what we mean, mean what we say, say what we mean, and know what we have said.

Therefore, in this perspective, this is no doubt partly because Sophocles' "Oedipus Rex" employs a wide array of binary structuring devices (youth versus age, life versus death, master versus slave, man versus woman, punishment verses crime, knowledge versus ignorance, fate versus fated man, light versus darkness, virtue versus evil, nature versus culture ) ripe Derridean deconstructive analysis. The wide array of binary oppositions in the text of the play show how the slave-owning Greek social formation can only ever imagine its "other" as chaos rather than unity, and is thus bound to define the supernatural powers as the gods and the logi.

However, the characters of the play seem to try to perceive their life and entity in terms of binary oppositions. For example, when Oedipus answered the riddle of Sphinx, he only highlighted man but suppressed woman in the opposite pair of man and woman, not mentioning anything about her in his answer. In this way, in somewhere else in the play, Oedipus says about all-round and unbound god-gifted knowledge of Teiresias, the blind seer, which possesses binarism of sacred and profane, heavenly and earthly or natural and supernatural phenomena in itself:

"Teiresias, we know there is nothing beyond your ken;

Lore sacred and profane, all heavenly and earthly knowledge

Are in your grasp. In your heart, if not with eyes," (Sophocles, 1947, p. 34)

Moreover, Oedipus again describes the world around him in the end of the play in the terms of binary oppositions between the phenomena of beauty and ugliness in the following words:

"Where all is ugliness?

Where is there any beauty

For me to see?" (Sophocles, 1947, p. 34) 


\section{Conclusion}

The present study tries to analyse the text of the play "Oedipus Rex" in a new and innovative way, discussing the different facets of this famous play from Derridean deconstructive perspective. The chief objective of this study is to push Sophocles' "Oedipus Rex" within Derridean deconstructive perspective for investigating and scrutinizing the structure and meaning of the text of the play. Therefore, this research paper tends to investigate and scrutinize the text of the play. In this manner, the study focuses the text of the play to deconstruct and dismantle the fixity, singularity, fossilized and unified meaning of it. The study also discusses the nature and influences of messianic theocentric as well as anthropocentric logocentrism on human thought, which plays significant function in the lives, thought and psyche of the characters of the highly debate raging play "Oedipus Rex".

The study concludes how Western logocentric tradition of the metaphysics of presence from Plato's "Phaedrus" to Edmund Husserl's "Origin of Geometry" and its compelling aporetic influences and repercussions ground human thought in stable, fixed and pre-determined meaning. In its concluding mode, the study analyses preventive stumbling aporic blocks of fossilized messianic logocentric structure of the minds of characters in the play.

\section{References}

Habib, M.A.R. (2005). A History of Literary Criticism: From Plato to the Present. Malden: Blackwell Publishing.

Derrida, J. (1997). Of Grammatology. Baltimore. MD: the John Hopkins University Press.

Derrida, J. (2005).Writing and Difference. London and New York: Routledge.

Derrida, J. (2007). Psyche, Inventions of the Other, Volume 1. Palo Alto, CA: Stanford University Press.

Derrida, J. (1981). Positions. Chicago: the University of Chicago Press.

Derrida, J. (1982). Margins of Philosophy. Hertfordshire: Harvester.

Derrida, J. (1998). Limited Inc. Illinois, Northwestern University Press.

Derrida, J. (1989). Memoires for Paul De Man. New York: Columbia University Press.

Levi-Strauss, C. (1974). Structural Anthropology. Trans. Claire Jacobson and Brooke Schoepf. New York: Basic Books.

Parray, A.H. (2013). A Postmodern Interpretation of Oedipus Rex. Language in India 13, 106-111.

Sophocles. (1947). The Theban Plays. London: Penguin Books. 